\title{
Effect of industry on the content of fatty acids in the tissues of the honey-bee head
}

\author{
V.Y. Vishchur ${ }^{1}$, B.V. Gutyj ${ }^{1}$, N.P. Nischemenko ${ }^{2}$, I.M. Kushnir ${ }^{3}$, V.Z. Salata ${ }^{1}$, L.O. Tarasenko ${ }^{4}$, \\ M.S. Khimych ${ }^{4}$, V.I. Kushnir ${ }^{3}$, B.M. Kalyn ${ }^{1}$, N.V. Magrelo ${ }^{1}$, P.K. Boiko ${ }^{5}$, V.A. Kolotnytskyy ${ }^{1}$, \\ T. Velesyk ${ }^{6}$, T.O. Pundyak ${ }^{1}$, O.P. Gubash ${ }^{7}$ \\ ${ }^{1}$ Stepan Gzhytskyi National University of Veterinary Medicine and Biotechnologies, Lviv, Ukraine \\ ${ }^{2}$ Bila Tserkva National Agrarian University, Bila Tserkva, Ukraine \\ ${ }^{3}$ State Scientific-Research Control Institute of Veterinary Medicinal Products and Feed Additives, Lviv, Ukraine \\ ${ }^{4}$ Odessa State Agrarian University, Odessa, Ukraine \\ ${ }^{5}$ Lesya Ukrainka Eastern European National University, Lutsk, Ukraine \\ ${ }^{6}$ National University of Water Management and Nature, Rivne, Ukraine \\ 'Boris Grinchenko Kyiv University, Kyiv, Ukraine \\ E-mail: v.vishchur@gmail.com, $\underline{\text { bvh@ukr.net }}$
}

Received: 27.09.2019. Accepted: 27.10.2019

\begin{abstract}
The tissues of the head of honey bees which are kept in the areas with a medium and low level of technogenic burden demonstrate the decrease in the contents of iron, zinc, copper, chromium, nickel, lead and cadmium in comparison with the tissues of the head of honey bees grown in areas with a high level of technogenic burden. Due to the activity of saturated fatty acids with the even and odd number of carbon atoms in chain, monounsaturated fatty acids of n-7 and n-9 families and polyunsaturated fatty acids of n-3 and $n-6$ families, the contents of anionic fatty acids, which are inaccessible for the bee body, decreases in the tissues of the head of honey bees which are kept in the areas with a medium and low level of technogenic burden in comparison with the tissues of the head of honey bees grown in areas with a high level of technogenic burden. 3. Monounsaturated fatty acids of $n-7$ and $n-9$ families and polyunsaturated fatty acids of $n-3$ and $n-6$ families in the tissues of the head of honey bees lead to increase of the total number of easily accessible non-esterified fatty acids for the honey bees which are kept in the areas with a medium and low level of technogenic burden in comparison with the tissues of the head of honey bees grown in areas with a high level of technogenic burden. Furthermore, the intensity of transformations of the non-esterified form of linolenic acid in its more long-chain and more unsaturated derivatives rises in the head tissues of the former. This fact indicates that the reduction of technogenic impact on the area results in the increase of the activity of desaturase in the tissues of the head of honey bees. The contents of heavy metals, anionic and non-esterified fatty acids in the tissues of the head of honey bees which are kept in the areas with low level of technogenic burden undergoes the most significant changes.
\end{abstract}

Keywords: Fatty acids; Tissues of honey bee heads; Technogenic burden on the environment

\section{Introduction}

The industrial, agricultural, energetic and transport development, as well as the intensive extraction of minerals lead to an increase of heavy metal contents in the air, water, soil, plants and pollen (Conti \& Botre, 2001; Gutyj et al., 2016; Khariv \& Gutyj, 2016; Martyshuk et al., 2016; Gutyj et al., 2017; Gutyj). Thus, heavy metals began to intensively accumulate in the tissues of honey bees and beekeeping products (Kovalchuk \& Fedoruk, 2008; Vishchur et al., 2016).

On the other hand, fatty acids are a vital component of the honey bee nutrition. In particular, the fatty acid composition of the plant pollen affects the productive and reproductive characteristics of the body of the honey bee. In addition, fatty acids in the body of honey bees are deposited in the body fat reserve and are used if necessary (Kovalskyi et al., 2018).

The exchange of fatty acids in the body of honey bees is closely connected to the exchange of mineral elements (Lebedev \& Bilash, 1991). Particularly, the activity of a number of enzymes which take part in the elongation of the carbon chain of fatty acids and the formation of unsaturated bonds in it depends on copper and zinc.The amount of fatty acids that are found in the pollen, tissues of honey bees and bee products in anionic form depends on the main mineral elements, including heavy metals, and to the greatest extent - bivalent ones. The latter affect the biological value of feed and beekeeping products, primarily pollen, cerago and honeycombs (Bogdanov et al., 2007). Taking into account all mentioned above, the study of the contents of heavy metals, anionic and non-esterified forms of fatty acids in the tissues of the head of honey bees dependent on the level of anthropogenic pressure on the environment is of significant scientific and practical interest (Vishchur et al., 2016; Brodschneider \& Crailsheim, 2010).

The aim of the research was to determine the contents of heavy metals, anionic and non-esterified fatty acids in the tissues of the head of honey bees dependent on the level of anthropogenic pressure on the environment.

\section{Materials and Methods}

The level of man-made impact was determined by the contents of pollen from Dandelion Medicinal (Taraxacum officinale Wigg.), heavy metals (Iron, Zinc, Copper, Chromium, Nickel, Plumbum, Arsenic and Cadmium). 
Samples of pollen from Dandelion Medicinal and Carpathian honey bees for laboratory research were taken in the apiaries which are situated in the locations with different traffic intensity of and industrial enterprises burden. The experiment locations were: the training apiary of the Stepan Gzhytskyi National University of Veterinary Medicine and Biotechnologies Lviv (territory with very heavy traffic and work of industrial enterprises) and in private beekeeping enterprises in Vynnyky town and Chyzhykiv village, Pustomyty, Lviv region (territories with less traffic and lower work intensity of industrial enterprises). Private beekeeping enterprises of Vynnyky and Chyzhykiv are respectively located at a distance of 2-3 and 5-6 km from the training apiary of the Stepan Gzhytskyi National University of Veterinary Medicine and Biotechnologies Lviv. Moreover, Stepan Gzhytskyi National University of Veterinary Medicine and Biotechnologies Lviv and private beekeeping enterprises in Vynnyky and with Chyzhykiv in Pustomyty district of Lviv region are located along the Lviv-Ternopil highway.

Samples of the pollen from dandelion and tissues of the heads of honey bees were collected in each of the aforementioned experimental sites. The pollen samples from dandelion and head tissue of honey bees were taken from three hives in each apiary. To clarify the species of the pollen from Dandelion Medical, the identity research was conducted using the computer programs "LUCIA" (Laboratory Colour Image Analysis) and "Pollen Data Bank".

The contents of heavy metals was determined in selected samples of bee pollen determined. The selected samples of the head tissues of honey bees were explored in terms of concentration of heavy metals, anionic and non-esterified forms of fatty acids. The contents of heavy metals in the investigated biological material was studied using the atomic and absorption spectrophotometer C115 PC. Concentration of anionic and non-esterified forms of fatty acids in the biological material under investigation was determined by gas-liquid chromatography.

Samples of bee pollen and honey bee head tissues were put into atomic absorption analyzer in the form of solutions obtained by dry ozonation and dissolution of ash in concentrated hydrochloric acid.

To determine the contents of anionic forms of fatty acids, the biological material under investigation was processed with various extraction mixtures. In one case, it was treated with the mixture of chloroform-methanol-hydrochloric acid (200: 100: 1 by volume), and in the other one - with chloroform-methanol ( $2: 1$ by volume). In both cases, lipids released from chloride were smeared and the fatty acids obtained as a result were methylated. Methyl esters of fatty acids, obtained in both cases, were added into the evaporator of a gas-liquid chromatographic equipment.

The difference in the contents of fatty acids was the difference in their anionic forms. The contents of non-esterified forms of fatty acids in the investigated biological material was determined by extraction of lipids with a mixture of chloroform-methanol ( 2 : 1 by volume). By using sodium methylate, we isolated non-esterified forms of fatty acids from chloroform extract of lipids. The latter were methylated with methanol and acetyl chloride. Obtained methyl esters of fatty acids were put into the evaporator of a gasliquid chromatographic equipment.

The separation of methyl esters of fatty acids was carried out on chromatography Chrom-5 (Laboratorni Presta, Prague). A 3700 $\mathrm{mm}$ long stainless steel column with an internal diameter of $3 \mathrm{~mm}$ was filled with Chromaton-N-AW, particle size $60-80$ mesh, silaneated HMDS (hexamethyldisilazine) and coated with polydyethylene glycol dipinat (stationary liquid phase) in the amount of $10 \%$.

Identification of peaks on the chromatogram was carried out by the method of calculating "carbon numbers", as well as by using chemically pure, standard solutions, methyl esters of fatty acids. Calculation of the contents of certain fatty acids based on the results of gas chromatographic analysis, chromatograms, were carried out using the formula that includes correction factors for each of them. Correction factors were determened as the ratio of peak areas (in particular peak heights) of heptadecanoic (internal standard) and the investigated acids at a concentration of $1: 1$ and isothermal mode of operation of the gas-liquid chromatograph (Vlizlo, 2012).

The obtained digital material was processed using the method of variation statistics using Student's t-test. Average arithmetic meanings and average arithmetic mean errors were calculated. Changes were considered probable at $\mathrm{p}<0.05$. A special computer application, Origin 6.0, Excel (Microsoft, USA), was used for calculations.

\section{Results and Discussion}

It was discovered that the levels of iron, zinc, copper, chromium, nickel, lead and cadmium are likely to decrease in the tissues of the head of honey bees which are kept in the areas of a medium and low level of technogenic burden and stated that in comparison with the tissues of the head of honey bees grown in the area with a high level of technogenic burden (Table 1).

Table 1. Heavy metal concentration in the tissues of honey bee heads, $\mathrm{mg} / \mathrm{kg}$ natural weight $(M \pm m, n=3)$

\begin{tabular}{lccc}
\hline \multicolumn{1}{c}{$\begin{array}{c}\text { Heavy metals and } \\
\text { their symbols }\end{array}$} & High & Level of technogenic burden & Low \\
\cline { 2 - 4 } & $35.21 \pm 1.351$ & $27.25 \pm 1.814^{*}$ & $21.17 \pm 0.936^{* * *}$ \\
Ferum, Fe & $44.13 \pm 2.123$ & $35.60 \pm 2.056^{*}$ & $31.21 \pm 1.749 * * *$ \\
Zinc, Zn & $17.47 \pm 0.826$ & $11.32 \pm 0.718^{* *}$ & $5.49 \pm 0.292^{* * *}$ \\
Copper, Cu & $9.77 \pm 0.486$ & $5.98 \pm 0.307^{* * *}$ & $4.55 \pm 0.231^{* * *}$ \\
Nickel, Ni & $1.82 \pm 0.098$ & $1.06 \pm 0.058^{* * *}$ & $0.70 \pm 0.032^{* * *}$ \\
Lead, Pb & $1.70 \pm 0.081$ & $1.33 \pm 0.084^{*}$ & $1.13 \pm 0.052^{* *}$ \\
Cadmium, Cd & $0.12 \pm 0.009$ & $0.09 \pm 0.006^{*}$ & $0.08 \pm 0.006^{*}$ \\
\hline
\end{tabular}

Note: hereinafter $*-\mathrm{p}<0.02-0.05 ; * *-\mathrm{p}<0.01 ; * * *-\mathrm{p}<0.001$

It was found out that the contents of anionic and non-esterified forms of fatty acids in the tissues of the head of honey bees which are kept in the areas with a medium and low level of technogenic burden changes in comparison with the one in the tissues of the head of honey bees grown in the areas with a high level of technogenic burden. It affects their energy, functional and metabolic and biological value of the honey bee body (Polishchuk, 2001; Howton \& Mead, 1991).

The amount of fatty acids, which are presented in in the tissues of honey bees in their anionic form, depends on the mineral elements, in particular on the bivalent ones. This is due to the fact that non-esterified fatty acids can bind heavy mineral elements. However, the mineral elements in the tissues of honey bees are closely linked to the exchange of fatty acids. So, the activity of 
enzymes that are involved in the elongation of the carbon chain of a fatty acid and the formation of unsaturated bonds in it depends on copper and zinc (Bohdanov et al., 2003).

We have found that the total concentration of anionic forms of fatty acids in the tissues of the heads of honey bees which are kept in the areas with a medium and low level of technogenic burden is lower compared to the tissues of the head of honey bees grown in the territories with a high level of technogenic burden (Table. 2). Reducing the concentration of anionic forms of fatty acids in the tissues of the head of honey bees which are kept in the areas with a medium and low level of technogenic burden indicates an increase in the quantity of non-esterified forms of fatty acids. An increase in the number of the latter may indicate an increase in their energetic, functional, metabolic and biological value for the tissues of honey bees. I can be explained by the fact that the anionic forms of fatty acids, unlike non-esterified, are inaccessible to the body of honey bees.

Table 2. Level of anionic forms of fatty acids in the tissues of honey bee heads, $g^{-3} / \mathrm{kg}$ natural weight $(M \pm m, n=3)$

\begin{tabular}{|c|c|c|c|}
\hline \multirow{2}{*}{$\begin{array}{c}\text { Anionic fatty acids and } \\
\text { their code }\end{array}$} & \multicolumn{3}{|c|}{ Level of technogenic burden } \\
\hline & High & Medium & Low \\
\hline Caprylic, 8:0 & $0.6 \pm 0.06$ & $0.3 \pm 0.06^{*}$ & $0.2 \pm 0.06 * *$ \\
\hline Capric, 10:0 & $0.8 \pm 0.06$ & $0.5 \pm 0.06 *$ & $0.4 \pm 0.06 * *$ \\
\hline Lauric, $12: 0$ & $1.1 \pm 0.06$ & $0.8 \pm 0.06 *$ & $0.7 \pm 0.06 * *$ \\
\hline Myristic, $14: 0$ & $2.8 \pm 0.11$ & $2.3 \pm 0.11^{*}$ & $2.2 \pm 0.11^{* *}$ \\
\hline Pentadecanoic, 15:0 & $4.2 \pm 0.11$ & $3.7 \pm 0.09 *$ & $3.7 \pm 0.12^{*}$ \\
\hline Palmitic, $16: 0$ & $47.4 \pm 1.68$ & $41.5 \pm 1.23^{*}$ & $40.1 \pm 1.10^{*}$ \\
\hline Palmitooleic, 16:1 & $2.0 \pm 0.11$ & $1.6 \pm 0.06^{*}$ & $1.5 \pm 0.06 * *$ \\
\hline Stearic, 18:0 & $33.9 \pm 1.50$ & $28.8 \pm 1.07^{*}$ & $27.7 \pm 0.79 *$ \\
\hline Oleic, 18:1 & $125.1 \pm 6.41$ & $103.4 \pm 5.05^{*}$ & $100.3 \pm 4.04^{*}$ \\
\hline Linoleic, $18: 2$ & $104.1 \pm 3.36$ & $91.5 \pm 2.14^{*}$ & $90.1 \pm 2.20 *$ \\
\hline Linolenic, 18:3 & $112.9 \pm 4.27$ & $97.6 \pm 3.18^{*}$ & $95.8 \pm 2.95^{*}$ \\
\hline Arachidic, 20:0 & $5.1 \pm 0.17$ & $4.4 \pm 0.14^{*}$ & $4.2 \pm 0.11^{* *}$ \\
\hline Eicosanoic, 20:1 & $7.0 \pm 0.20$ & $5.9 \pm 0.20 * *$ & $5.6 \pm 0.23 * *$ \\
\hline Eicosadienoic, 20:2 & $5.7 \pm 0.17$ & $4.9 \pm 0.17^{*}$ & $4.6 \pm 0.20 * *$ \\
\hline Eicosatrienoic, 20:3 & $3.9 \pm 0.14$ & $3.3 \pm 0.14^{*}$ & $3.2 \pm 0.12^{* *}$ \\
\hline Arachidonic, $20: 4$ & $115.5 \pm 5.02$ & $96.9 \pm 4.14^{*}$ & $93.9 \pm 4.29 *$ \\
\hline Eicosapentaenoic, 20:5 & $74.8 \pm 2.11$ & $67.6 \pm 1.74^{*}$ & $65.0 \pm 1.68^{*}$ \\
\hline Docosadienoic, 22:2 & $6,9 \pm 0.17$ & $6.1 \pm 0.17^{*}$ & $5.8 \pm 0.14 * *$ \\
\hline Docosatrienoic, 22:3 & $7.0 \pm 0.23$ & $6.1 \pm 0,17^{*}$ & $5.7 \pm 0.12^{* *}$ \\
\hline Docosatetraenoic, 22:4 & $13.6 \pm 0.35$ & $12.0 \pm 0.37 *$ & $11.6 \pm 0.26 * *$ \\
\hline Docosapentanoic, $22: 5$ & $32.4 \pm 1.23$ & $26.4 \pm 1.31^{*}$ & $24.6 \pm 0.55^{* *}$ \\
\hline Docosahexaenoic, 22:6 & $39.8 \pm 1.56$ & $34.7 \pm 0.98^{*}$ & $33.5 \pm 0.48^{* *}$ \\
\hline Total level of anionic fatty acids & 746.6 & 640.3 & 620.4 \\
\hline Including saturated & 95.9 & 82.3 & 79.2 \\
\hline Monounsaturated & 134.1 & 110.9 & 107.4 \\
\hline Polyunsaturated & 516.6 & 447.1 & 433.8 \\
\hline$n-3 / n-6$ & 1.19 & 1.20 & 1,19 \\
\hline
\end{tabular}

The lower level of anionic forms of fatty acids in the tissues of the head of honey bees which are kept in the areas with a medium and low level of technogenic burden in comparison with the tissues of the head of honey bees grown in areas with a high level of technogenic burden is caused by lower contents of saturated fatty acids in their composition with even (78.6 and 75.5 against 91.7 $\mathrm{g}^{-3} / \mathrm{kg}$ of natural weight correspondingly) and odd (3.7 and 3.7 against 4.2) number of carbon atoms in the chain, monounsaturated fatty acids of $n-7$ family (1.6 and 1.5 against 2.0) and n-9 family (109.3 and 105.9 against 132.1 ) and polyunsaturated fatty acids of n-3 (244.4 and 236.2 against 280.5) and n-6 families (respectively 202.7 and 197.6 against $236,1 \mathrm{~g}^{-3} / \mathrm{kg}$ of natural weight). Thus, the ratio of the anionic polyunsaturated fatty acids of the $n-3$ family to the anionic polyunsaturated fatty acids of the n- 6 family is 1.20 and 1.19 versus 1.19 .

Table 2 demonstrates that the tissues of the head of honey bees which are kept in the areas with a medium and low level of technogenic burden, in comparison with the tissues of the head of honey bees grown in areas with a high level of technogenic burden, are likely to undergo the decrease in concentration of such anionic forms of saturated fatty acids as caprylic, capric, lauric, myristic, pentadecanoic, palmitic, stearic, and arachidic; monounsaturated - palmitoleic, oleic and eicosanoic; polyunsaturated - linoleic, linolenic, eicosadienoic, eicosatrienoic, eicosatetraenoic (arachidonic), eicosapentaenoic, docosadienoic, docosatrienoic, docosatetraenoic, docosapentanoic and docosahexaenoic.

Non-esterified forms of fatty acids are the most metabolically active. The research concluded that the total contents of nonesterified forms of fatty acids in the tissues of the head of honey bees which are kept in the areas with a medium and low level of technogenic burden increases in comparison with the tissues of the head of honey bees grown in areas with a high level of technogenic burden (Table 3). The highest total contents of non-esterified forms of fatty acids was found in the tissues of the head of honey bees which are kept in the areas with a low level of technogenic burden.

The greater total amount of non-esterified forms of fatty acids in the tissues of the heads of honey bees which are kept in the areas with a medium and low level of technogenic burden, compared to the tissues of the head of honey bees, is conditioned by monounsaturated fatty acids of $n-7$ (correspondingly 3.1 and 3.3 against $2.6 \mathrm{~g}^{-3} / \mathrm{kg}$ of natural weight) and $n-9$ families (187.0 and 191.7 against 164.8), and especially polyunsaturated fatty acids of n-3 (435.3 and 444.5 against 375.3 ) and n-6 families (347.6 and 356.0 against $296.2 \mathrm{~g} \mathrm{~g}^{-3} / \mathrm{kg}$ of natural weight respectively). At the same time, the tissues of the head of honey bees which are kept in the areas with a medium and low level of technogenic burden increases, in comparison with the tissues of the head of honey bees grown in areas with a high level of technogenic burden, demonstrate the intensity of transformations of the non-esterified form of linolenic acid in its more long-chain and more unsaturated derivatives ( 0.57 and 0.56 against 0.71 respectively). 
Moreover, the intensity of transformations of the non-esterified form of linoleic acid in its more long-chain and more unsaturated derivatives ( 0.74 and 0.73 against 0.74 respectively) does not change.

It is worth mentioning that the tissues of the head of honey bees which are kept in the areas with a medium and low level of technogenic burden increases, in comparison with the tissues of the head of honey bees grown in areas with a high level of technogenic burden, demonstrate the decrease in the amount of non-esterified forms of saturated fatty acids with even (100.3 and 96.9 against $118.9 \mathrm{~g}^{-3} / \mathrm{kg}$ of natural weight respectively) and odd (4.4 and 4.2 against $5.2 \mathrm{~g}^{-3} / \mathrm{kg}$ of natural weight respectively) number of carbon atoms in the chain.

The increase in the total contents of non-esterified forms of fatty acids in the tissues of the head of honey bees which are kept in the areas with a medium and low level of technogenic burden may mean an increase in their energetic, functional and metabolic and biological values (Burmistrova et al., 2008).

Fatty acids exert antibacterial and antifungal effect. The shorter the carbon chain of saturated fatty acids is the more they provide antibacterial and antifungal protection of the honey bee body. The antibacterial and antifungal effect of fatty acids also grows with the increase in the number of unsaturated bonds in their carbon chain. Therefore, these fatty acids play an important role in the hygiene of honey bees (Saranchuk \& Rivis, 2009).

It has been noticed that the total contents of non-esterified forms of short-chain saturated fatty acids (10 and less carbon atoms in the chain) and polyunsaturated fatty acids (18 and more carbon atoms in the chain) that provide antibacterial and antifungal protection of the honey bee body is higher in the tissues of the head of honey bees which are kept in the areas with a medium and low level of technogenic burden increasescompared to the tissues of the head of honey bees grown in areas with a high level of technogenic burden - 971.2 and 993.3 against $838.3 \mathrm{~g}^{-3} / \mathrm{kg}$ of natural weight respectively. It mainly increases in the tissues of the head of honey bees which are kept in the areas with a low level of technogenic burden.

The tissues of the honey bee head contain a big total number of easily accessible non-esterified form of unsaturated fatty acids palmitooleic, oleic, eicosanoic, linoleic, linolenic, eicosadienoic, eicosatrienoic, eicosatetraenoic (arachidonic), eicosapentaenoic, docosadienoic, docosatrienoic, docosatetraenoic, docosapentanoic and docosahexaenoic. A very high contents of unsaturated fatty acids in the tissues of honey bees can contribute to the growth of the permeability of their structural components for water and water-soluble substances (Lebedev \& Bilash, 1991).

We found that the total contents of non-esterified forms of unsaturated fatty acids in the tissues of the heads of honey bees that are kept in the areas with a medium and low level of technogenic burden, in comparison with the tissues of the head of honey bees grown in areas with a high level of technogenic burden, are higher (973.0 and 995.5 against $838.9 \mathrm{~g}-3 / \mathrm{kg}$ of natural weight respectively).

The data in Table 3 show that the contents of such non-esterified forms of saturated fatty acids as caprylic, capric, lauric, myristic, pentadecanoic, palmitic, stearic, and arachidic is likely to decrease in the tissues of the head of honey bees which are kept in the areas with a medium and low level of technogenic burden in comparison with the tissues of the head of honey bees grown in the area of a high level of technogenic load.

Table 3. Concentration of non-esterified forms of fatty acids in tissues of honey bee heads, $g^{-3} / \mathrm{kg}$ natural weight $(M \pm m, n=3)$

\begin{tabular}{|c|c|c|c|}
\hline \multirow{2}{*}{$\begin{array}{c}\text { Non-esterified forms of fatty acids in } \\
\text { tissues of honey bee heads }\end{array}$} & \multicolumn{3}{|c|}{ Level of technogenic burden } \\
\hline & High & Medium & Low \\
\hline Caprylic, 8:0 & $0.8 \pm 0.06$ & $0.5 \pm 0.06^{*}$ & $0.4 \pm 0.06 * *$ \\
\hline Capric, 10:0 & $1.2 \pm 0.11$ & $0.8 \pm 0.06^{*}$ & $0.7 \pm 0.06^{* *}$ \\
\hline Lauric, 12:0 & $1.7 \pm 0.11$ & $1.3 \pm 0.06^{*}$ & $1.2 \pm 0.06^{* *}$ \\
\hline Myristic, 14:0 & $3.6 \pm 0.11$ & $3.2 \pm 0.06^{*}$ & $3.1 \pm 0.06^{* *}$ \\
\hline Pentadecanoic, 15:0 & $5.2 \pm 0.23$ & $4.4 \pm 0.17^{*}$ & $4.2 \pm 0.14^{* *}$ \\
\hline Palmitic, $16: 0$ & $60.4 \pm 2.54$ & $50.4 \pm 2.40 *$ & $48.6 \pm 1.97 *$ \\
\hline Palmitooleic, $16: 1$ & $2.6 \pm 0.11$ & $3.1 \pm 0.14^{*}$ & $3.3 \pm 0.15^{* *}$ \\
\hline Stearic, $18: 0$ & $44.4 \pm 1.59$ & $38.5 \pm 1.69 *$ & $37.5 \pm 1.57 *$ \\
\hline Oleic, $18: 1$ & $155.5 \pm 4.97$ & $175.4 \pm 6.49$ & $179.6 \pm 5.91^{*}$ \\
\hline Linoleic, $18: 2$ & $126.2 \pm 4.49$ & $148.4 \pm 6.84 *$ & $150.8 \pm 6.18^{*}$ \\
\hline Linolenic, $18: 3$ & $156.2 \pm 6.06$ & $174.9 \pm 4.23 *$ & $177.3 \pm 4.04 *$ \\
\hline Arachidic, 20:0 & $6.8 \pm 0.35$ & $5.6 \pm 0.23^{*}$ & $5.4 \pm 0.20 *$ \\
\hline Eicosanoic, 20:1 & $9.3 \pm 0.40$ & $11.6 \pm 0.53^{*}$ & $12.1 \pm 0.46^{* *}$ \\
\hline Eicosadienoic, $20: 2$ & $7.4 \pm 0.35$ & $8.9 \pm 0.32 *$ & $9.3 \pm 0.26^{* *}$ \\
\hline Eicosatrienoic, 20:3 & $5.2 \pm 0.26$ & $6.4 \pm 0.26^{*}$ & $6.7 \pm 0.17^{* *}$ \\
\hline Arachidonic, 20:4 & $148.3 \pm 6.87$ & $172.2 \pm 4.59 *$ & $177.1 \pm 4.20 *$ \\
\hline Eicosapentaenoic, 20:5 & $97.9 \pm 4.17$ & $114.8 \pm 3.88^{*}$ & $117.6 \pm 3.52 *$ \\
\hline Docosadienoic, 22:2 & $9.1 \pm 0.66$ & $11.7 \pm 0.43^{*}$ & $12.1 \pm 0.40 * *$ \\
\hline Docosatrienoic, 22:3 & $9.4 \pm 0.69$ & $12.2 \pm 0.46^{*}$ & $12.7 \pm 0.43^{* *}$ \\
\hline Docosatetraenoic, 22:4 & $18.4 \pm 0.95$ & $22.7 \pm 0.70 *$ & $23.3 \pm 0.59 * *$ \\
\hline Docosapentanoic, 22:5 & $39.1 \pm 1.51$ & $46.4 \pm 1.51^{*}$ & $47.6 \pm 1.37 * *$ \\
\hline Docosahexaenoic, 22:6 & $54.3 \pm 2.37$ & $64.3 \pm 2.29 *$ & $66.0 \pm 2.02 * *$ \\
\hline Total level of anionic fatty acids & 963.0 & 1077.7 & 1096.6 \\
\hline Including saturated & 124.1 & 104.7 & 101.1 \\
\hline Monounsaturated & 167.4 & 190.1 & 195.0 \\
\hline Polyunsaturated & 671.5 & 782.9 & 800.5 \\
\hline$n-3 / n-6$ & 1.27 & 1.25 & 1.25 \\
\hline
\end{tabular}


However, we can observe the growth of content of such monounsaturated fatty acids as palmitooleic and eicosanoic and such polyunsaturated fatty acids as linoleic, linolenic, eicosadienoic, eicosatrienoic, eicosatetraenoic (arachidonic), eicosapentaenoic, docosadienoic, docosatrienoic, docosatetraenoic, docosapentanoic and docosahexaenoic. In addition, the level of such non-esterified monounsaturated fatty acid as olein gets higher in tissues of the head of honey bees which are kept in the area with a low level of technogenic impact. The information reviewed above is intended to state that the reduction of the technogenic burden on the environment leads to the increase of metabolic and biological value of non-esterified forms of fatty acids for the tissues of the head of honey bees.

\section{Conclusion}

The tissues of the head of honey bees which are kept in the areas with a medium and low level of technogenic burden demonstrate the decrease in the contents of iron, zinc, copper, chromium, nickel, lead and cadmium in comparison with the tissues of the head of honey bees grown in areas with a high level of technogenic burden.

Due to the activity of saturated fatty acids with the even and odd number of carbon atoms in chain, monounsaturated fatty acids of n-7 and n-9 families and polyunsaturated fatty acids of n-3 and n-6 families, the contents of anionic fatty acids, which are inaccessible for the bee body, decreases in the tissues of the head of honey bees which are kept in the areas with a medium and low level of technogenic burden in comparison with the tissues of the head of honey bees grown in areas with a high level of technogenic burden. Monounsaturated fatty acids of n-7 and n-9 families and polyunsaturated fatty acids of n-3 and n-6 families in the tissues of the head of honey bees lead to increase of the total number of easily accessible non-esterified fatty acids for the honey bees which are kept in the areas with a medium and low level of technogenic burden in comparison with the tissues of the head of honey bees grown in areas with a high level of technogenic burden. Furthermore, the intensity of transformations of the non-esterified form of linolenic acid in its more long-chain and more unsaturated derivatives rises in the head tissues of the former. This fact indicates that the reduction of technogenic impact on the area results in the increase of the activity of desaturase in the tissues of the head of honey bees. The contents of heavy metals, anionic and non-esterified fatty acids in the tissues of the head of honey bees which are kept in the areas with low level of technogenic burden undergoes the most significant changes.

\section{References}

Bogdanov, S., Haldimann, M., Luginbuhl, W., \& Gallmann, P. (2007). Minerals in honey: environmental, geographical and botanical aspects. Jornal of Apicultural Research and Bee World, 46(4), 269-275. doi: 10.3896/IBRA.1.46.4.11.

Bohdanov, H. O., Polishchuk, V. P., Rivis, Y. F., \& Lokutova, O. A. (2003). Zhyrni kysloty pylku roslyn (bdzholynoho obnizhzhia) ta yikh rol v metabolichnykh protsesakh i zhyttiediialnosti bdzhil. Biolohiia tvaryn, 5(1-2), 149-158 (in Ukrainian).

Brodschneider, R., \& Crailsheim, K. (2010). Nutrition and health in honey bees. Apidologie, 41(3), 278-294. doi: 10.1051/apido/2010012.

Burmistrova, L. A., Rusakova, T. M., Lizunova, A. S., \& Repnikova, L. V. (2008). Osobennosti nakoplenija toksichnyh jelementov otdel'nymi produktami pchelovodstva. Sovremennye tehnologii proizvodstva i pererabotki medu. Proceed. Int. Cinf.. Novosibirsk, 13-19 (in Russian).

Conti, M. E., \& Botre, F. (2001). Honey bees and their products as potential bioindicators of heavy metals contamination. Environmental monitoring and assessment, 69(3), 267-282. doi: 10.1023/A:1010719107006.

Gutyj, B., Grymak, Y., Drach, M., Bilyk, O., Matsjuk, O., Magrelo, N., Zmiya, M., \& Katsaraba, O. (2017). The impact of endogenous intoxication on biochemical indicators of blood of pregnant cows. Regulatory Mechanisms in Biosystems, 8(3), 438-443. doi: $10.15421 / 021768$.

Gutyj, B., Martyshchuk, T., Bushueva, I., Semeniv, B., Parchenko, V., Kaplaushenko, A., Magrelo, N., Hirkovyy, A., Musiy, L., \& Murska, S. (2017). Morphological and biochemical indicators of blood of rats poisoned by carbon tetrachloride and subject to action of liposomal preparation. Regulatory Mechanisms in Biosystems, 8(2), 304-309. doi:10.15421/021748.

Gutyj, B., Paska, M., Levkivska, N., Pelenyo, R., Nazaruk, N., \& Guta, Z. (2016). Study of acute and chronic toxicity of 'injectable mevesel' investigational drug. Biological Bulletin of Bogdan Chmelnitskiy Melitopol State Pedagogical University, 6(2), 174-180. doi: $10.15421 / 201649$.

Gutyj, B., Stybel, V., Darmohray, L., Lavryshyn, Y., Turko, I., Hachak, Y., Shcherbatyy, A., Bushueva, I., Parchenko, V., Kaplaushenko, A., \& Krushelnytska, O. (2017). Prooxidant-antioxidant balance in the organism of bulls (young cattle) after using cadmium load. Ukrainian Journal of Ecology, 7(4), 589-596. doi: 10.15421/2017 165.

Gutyj, B.V., Murs'ka, S.D., Gufrij, D.F., Hariv, I.I., Levkivs'ka, N.D., Nazaruk, N.V., Gajdjuk, M.B., Pryjma, O.B., Bilyk, O.Ja., \& Guta, Z.A. (2016). Vplyv kadmijevogo navantazhennja na systemu antyoksydantnogo zahystu organizmu bugajciv. Visnyk Dnipropetrovs'kogo universytetu. Biologija, ekologija, 24(1), 96-102. doi: http://dx.doi.org/10.15421/011611 (in Ukrainian).

Gutyj, B.V., Ostapyuk, A.Y., Sobolev, O.I., Vishchur, V.J., Gubash, O.P., Kurtyak, B.M, Kovalskyi, Y.V., Darmohray, L.M., Hunchak, A.V., Tsisaryk, O.Y., Shcherbatyy, A.R., Farionik, T.V., Savchuk, L.B., Palyadichuk, O.R., Hrymak, K. (2019). Cadmium burden impact on morphological and biochemical blood indicators of poultry. Ukrainian Journal of Ecology, 9(1), $236-239$.

Howton, D. R., \& Mead, J. F. (1991). Metabolism of essential fatty acids. J. Biol. Chem, 235, 3385-3389.

Khariv, M.I., \& Gutyj, B.V. (2016). Vplyv liposomalnogo preparatu Butaintervit na proteinsyntezuvalnu funkciju pechinky shhuriv za otrujennja tetrahlormetanom. Visnyk Dnipropetrovskogo universytetu. Biologija, medycyna, 7(2), 123-126 doi: http://dx.doi.org/10.15421/021622 (in Ukrainian).

Kovalchuk, I. I., \& Fedoruk, R. S. (2008). Melliferous bees and honey are bioindicator contamination of environment by heavy metals. The Animal Biology, 10(1-2), 24-32.

Kovalskyi, Yu., Gucol, A. Gutyj, B., Sobolev, O., Kovalska, L., \& Mironovych, A. (2018). Features of histolism and hystogenesis in the vital temperature range in the organism of honey bee (Apis mellifera L.) in the postembrional period. Ukrainian Journal of Ecology, 8(2), 301-307. doi: http://dx.doi.org/10.15421/2018 342

Lebedev, V., \& Bilash, N. (1991). Biologija medonosnoj pchely [Honey Bee Biology]. Agopromizdat, Moscow (in Russian).

Martyshuk, T. V., Gutyj, B. V., \& Vishchur, O. I. (2016). Riven produktiv perekysnoho okysnennia lipidiv u krovi shchuriv za umov oksydatsiinoho stresu ta za dii liposomalnoho preparatu "Butaselmevit" [Level of lipid peroxidation products in the blood of rats under the influence of oxidative stress and under the action of liposomal preparation of "Butaselmevit"]. Biological Bulletin of Bogdan Chmelnitskiy Melitopol State Pedagogical University, 6(2), 22-27. doi: http://dx.doi.org/10.15421/201631(in Ukrainian).

Polishchuk, V. P. (2001). Bdzhilnytstvo. Lviv: Ukrainskyi pasichnyk (in Ukrainian). 
Vishchur, V.Y., Saranchuk, I.I., \& Gutyj, B.V. (2016). Fatty acid content of honeycombs depending on the level of technogenic loading on the environment. Visn. Dnìpropetr. Univ. Ser. Biol. Ekol., 24(1), 182-187. doi: http://dx.doi.org/10.15421/011622

Vlizlo, V.V. (2012). Laboratorni metody doslidzhen u biologiyi, tvarynnycztvi ta veterynarnij medycyni: Lviv: Spolom (in Ukrainian). Saranchuk, I. I., \& Rivis, Y. F. (2009). Vplyv ekolohichnykh umov dovkillia na vmist riznykh form zhyrnykh kyslot u tkanynakh cherevtsia medonosnykh bdzhil. Tekhnolohiia vyrobnytstva i pererobky produktsii tvarynnytstva. Zbirnyk naukovykh prats. Bila Tserkva, 1(67), 62-67 (in Ukrainian).

\section{Citation:}

Vishchur, V.Y., Gutyj, B.V., Nischemenko, N.P., Kushnir, I.M., Salata, V.Z., Tarasenko, L.O., Khimych, M.S., Kushnir, V.I., Kalyn, B.M., Magrelo, N.V., Boiko, P.K., Kolotnytskyy, V.A., Velesyk, T., Pundyak, T.O., Gubash, O.P. (2019). Effect of industry on the content of fatty acids in the tissues of the honey-bee head. Ukrainian Journal of Ecology, 9(3), 174-179. 